\title{
URGENSI PEMBENTUKAN DASAR HUKUM TERHADAP PROSES SISTEM PERADILAN PIDANA DI MASA PANDEMI COVID-19
}

\author{
Ratna Kumala Sari ${ }^{*}$, Faatir Al Insaani ${ }^{2}$ Ledi Vebriani $^{3}$ \\ Universitas Sang Bumi Ruwa Jurai \\ email: ratnakumala92@gmail.com
}

\begin{abstract}
Abstrak
Pandemi Covid-19 telah menjadi salah satu kekhawatiran masyarakat karena hanya dalam kurun waktu beberapa bulan terakhir ternyata turut berdampak diberbagai aspek, salah satunya yakni penegakan hukum dalam proses sistem peradilan pidana. Dalam merespon pandemi Covid-19, Negara perlu memastikan bahwa hak asasi setiap individu benar-benar dilindungi. Pandemi Covid-19 pun memaksa semua negara menata ulang sistem hukum mereka termasuk bagaimana sistem peradilan pidana beroperasi. Proses penegakan hukum pidana sebagai proses hukum yang tahapannya paling panjang dan melibatkan banyak pihak, baik warga selaku pelapor, kuasa hukum dan saksi, maupun instansi yang berkaitan. Hal ini tentu berkaitan dengan berjalannya Sistem Peradilan Pidana (Criminal Justice System) yang seharusnya berjalan dengan baik due process of law (peradilan cepat dan adil). Berdasarkan uraian tersebut maka memunculkan permasalahan, pertama bagaimana proses penegakan hukum dalam sistem peradilan pidana selama pandemi Covid-19? dan kedua Urgensi pembentukan dasar hukum terhadap proses penegakan hukum dalam sistem peradilan pidana dengan protokol kesehatan Covid-19?. Tujuan penelitian ini ialah untuk mengetahui proses penegakan hukum dalam sistem peradilan pidana selama pandemi Covid-19 dan mendorong pemerintah untuk membentuk dasar hukum terhadap proses penegakan hukum dalam proses sistem peradilan pidana dengan protokol kesehatan Covid-19. Untuk mengkaji pokok permasalahan penelitian ini maka digunakan metode penelitian yuridis normatif dengan spesifikasi penelitian deskriptif analitis yang bertumpu pada data sekumder. Dari hasil pembahasan dapat disimpulkan bahwa selama masa pandemi Covid-19 proses sistem peradilan pidana di Covid-19 digelar secara virtual dan urgensi pembentukan dasar hukum terhadap proses peradilan pidana diperlukan karena hukum acara pidana) di masa pandemi Covid-19 dipandang tidak sesuai lagi. KUHAP sebagai pedoman dasar dalam proses pelaksanaan perkara pidana hanya mengatur hal-hal yang sifatnya normal.
\end{abstract}

Kata kunci: Penegakan Hukum, Sistem Peradilan Pidana, Covid-19

\begin{abstract}
The Covid-19 pandemic has become one of the people's concerns because only in the last few months it has had an impact in various aspects, one of which is law enforcement in the criminal justice system process. In responding to the Covid-19 pandemic, the State needs to ensure that the human rights of every individual are truly protected. The Covid-19 pandemic has forced all countries to restructure their legal systems, including how the criminal justice system operates. The process of enforcing criminal law is a legal process with the longest stages and involves many parties, both citizens as reporters, attorneys and witnesses, as well as related agencies. This is of course related to the operation of the Criminal Justice System, which should run properly due to the due process of law (fast and fair trial). Based on this description, it raises problems, first how is the law enforcement process in the criminal justice system during the Covid-19 pandemic? and secondly, the urgency to establish a legal basis for the law enforcement process in the criminal justice system with the Covid19 health protocol? The purpose of this study is to determine the law enforcement process in the criminal justice system during the Covid-19 pandemic and to encourage the government to form a legal basis for the law enforcement process in the criminal justice system process with the Covid-19 health protocol. To examine the main problems of this research, a normative juridical research method is used with descriptive analytical research specifications that are based on secondary data. From the results of the discussion it can be concluded that during the Covid-19 pandemic, the criminal justice system process in Covid-19 was held virtually and the urgency of establishing a legal basis for the criminal justice process was needed because the criminal procedural law) during the Covid-19 pandemic was deemed inappropriate anymore. The Criminal Procedure Code as a basic guideline in the process of implementing criminal cases only regulates matters of a normal nature.
\end{abstract}

Keywords: Law Enforcement, Criminal Justice System, Covid-19 


\section{PENDAHULUAN}

Berawal dari kota Wuhan di Tiongkok, virus corona jenis baru menyebar ke berbagai negara di dunia dan menyebabkan timbulnya penyakit Covid-19. Sekitar 11 Maret 2010, Covid-19 ditetapkan sebagai pandemi oleh WHO. Kondisi ini jelas tidak boleh diremehkan karena hanya ada beberapa penyakit saja sepanjang sejarah yang digolongkan sebagai pandemi seperti influenza, flu babi, HIV/Aids dan sebagainya [1]. Pemerintah Indonesia pun baru mengumumkan pada tanggal 02 Maret 2020 bahwa terdapat 2 warga negara Indonesia yang positif corona setelah sempat berkontak dengan seorang warga negara Jepang yang positif terkena virus corona terlebih dahulu. Hingga bulan April 2020, sudah terdapat kurang lebih 10.000 jiwa terkena virus corona. Dalam merespons pandemi Covid-19, Negara perlu memastikan bahwa hak asasi setiap individu benar-benar dilindungi. Hal ini termasuk proses penegakan hukum pidana. Bahwa hukum acara pidana adalah mencari kebenaran materiil, oleh karena itu meski di masa pandemi Covid-19 semua asas-asas hukum acara pidana harus terjaga agar proses pengadilan untuk mempertahankan hukum materiil sesuai dengan sistem peradilan pidana. Untuk mendapatkan keadilan sesuai dengan perlindungan baik secara individu, masyarakat maupun negara. Seandainya dimungkinkan penanganan proses sistem peradilan pidana untuk menjaga peradilan cepat, sederhana, dan biaya ringan meskipun dilaksanakan secara virtual harus didasarkan pada dasar hukum yang kuat selevel peraturan perundang-undangan. Sedangkan hingga kini hanya ada surat edaran yang dikeluarkan oleh MA yakni Surat Edaran MA Nomor 1 Tahun 2020 tentang Pedoman Pelaksanaan Tugas Selama Masa Pencegahan Penyebaran Covid-19. Berdasarkan latar belakang tersebut dengan melihat perkembangan pandemi Covid-19 yang terus meningkat, maka penelitian ini merumuskan permasalahan penelitian, pertama Bagaimana proses penegakan hukum dalam sistem peradilan pidana selama pandemi Covid-19? dan kedua

Urgensi pembentukan dasar hukum terhadap proses penegakan hukum dalam sistem peradilan pidana dengan protokol kesehatan Covid-19?. Selanjutnya, penelitian ini menjadi urgent dilakukan untuk mengetahui proses penegakan hukum dalam sistem peradilan pidana selama pandemi Covid-19 dan mendorong pemerintah untuk membentuk dasar hukum terhadap proses penegakan hukum dalam sistem peradilan pidana dengan protokol kesehatan Covid-19. Berdasarkan pencarian literatur, sumber informasi lain, serta internet, penelitian yang memiliki fokus penelitian ada beberapa penelitian atau setidaknya hasil penelitian yang memiliki kaitan dengan penelitian penulis, antara lain: Jurnal dengan judul Membangun Budaya Hukum Persidangan Virtual (Studi Perkembangan Sidang Tindak Pidana via Telekonferensi tahun 2020 memiliki fokus kajian bahwa uji coba virtual di Kantor Kejaksaan pada umumnya dan Kantor Kejaksaan Kota Semarang khususnya selain menjadi kebutuhan selama periode Pandemi Covid-19 dilihat sebagai akumulasi dari perkembangan teknologi di Bidang informasi [2].

Penegakan hukum pidana merupakan salah satu bentuk dari upaya penanggulangan kejahatan. Penggunaan hukum pidana sebagai alat untuk penanggulangan kejahatan merupakan bagian dari kebijakan kriminal. Pada hakikatnya, sistem peradilan pidana merupakan suatu proses penegakan hukum pidana, oleh karena itu sistem peradilan pidana berhubungan erat sekali dengan peraturan perundang-undangan pidana itu sendiri baik hukum pidana subtantif maupun hukum acara pidana [3]. Secara yuridis dan faktual, subsistem Sistem Peradilan Pidana (Criminal Justice System) sebagai pengemban kekuasaan penegakan hukum. Dalam sistem peradilan pidana pelaksanan dan penyelenggaraan penegakan hukum pidana melibatkan badan-badan yang masing-masing memiliki fungsi sendiri-sendiri. Penegakan hukum yang mengandung prinsip proporsional adalah bagaimana penegakan hukum berjalan sedemikian rupa, sehingga tidak hanya menegakkan aturan normatifnya 
(aspek kepastian hukumnya), tetapi juga aspek filosofisnya (aspek dan nilai keadilannya), dimana dalam hal ini bertujuan untuk menuju terwujudnya penegakan hukum secara proporsional, sangat diperlukan meda dan perangkat yang namanya sistem peradilan [4]. Guna menciptakan efektivitas semua komponen sistem harus bekerja secara integral dalam arti suatu subsistem bekerja harus memperhatikan pula subsistem yang lainnya secara keseluruhan [5]. Adapun yang menjadi subsistem dari sistem peradilan pidana, antara lain:

a. Subsistem Penyidikan

Fungsi penyelidikan dan penyidikan yang dilakukan kepolisian adalah bagian dari pelaksanaan proses penegakan hukum hukum pidana. Secara integral merupakan bagian dari dari keseluruhan subsistem sistem peradilan pidana [6]. Posisi sentralnya dalam fungsi penyidikan adalah bertindak sebagai penegak hukum. Secara konseptual, sebagai pengemban fungsi penegakan hukum institusi ini harus bersifat independen dan merdeka.

b. Subsitem Penuntutan

Fungsi penuntutan adalah subsistem kedua setelah subsistem penyidikan dalam rangkaian sistem peradilan pidana. Penuntutan adalah tindakan penuntut umum untuk melimpahkan perkara pidana ke pengadilan negeri yang berwenang dalam hal dan menurut cara yang diatur dalam undang-undangan ini dengan permintaan supaya diperiksa dan diputus oleh hakim di sidang pengadilan.

c. Subsistem Pengadilan

Mahkamah Agung sebagai puncak peradilan membawa konsekuensi adanya one roof system, dalam penyelenggaraan sistem peradilan di Indonesia [7]. Pengadilan adalah salah satu proses dalam sistem peradilan pidana yang tidak dapat berjalan tanpa adanya prosesproses lainnya yang mendahului, yaitu penyidikan dan penuntutan [8].

d. Subsistem Lembaga Pemasyarakatan

LP adalah instansi teknis Direktorat Jenderal Pemasyarakatan yang bertanggungjawab pelaksanaan pembinaan narapidana (warga binaan), diatur dalam Undang-Undang No. 12 Tahun 1995 Tentang Pemasyarakatan. Lembaga Pemasyarakatan melaksanakan pidana yang dijatuhkan oleh Hakim berupa putusan pemidanaan khususnya pidana penjara.

Faktor-faktor yang mempengaruhi pelaksanaan sistem peradilan pidana dalam penegakan hukum pidana menurut [9] antara lain:

a. Faktor hukumnya sendiri

b. Faktor penegak hukum yaitu pihak-pihak yang membentuk maupun yang menerapkan hukum

c. Faktor sarana atau fasilitas yang mendukung penegakan hukum

d. Faktor masyarakat, yakni lingkungan di mana hukum tersebut diterapkan

e. Faktor kebudayaan, yakni sebagai hasil karya, cipta, dan rasa yang didasarkan pada karsa manusia di dalam pergaulan hidup.

\section{METODE PENELITIAN}

Metode pendekatan yang digunakan dalam penelitian ini ialah yuridis normatif yang mengacu pada data sekunder. Penelitian normatif seringkali disebut dengan penelitian doktrinal, yaitu penelitian yang objek kajiannya adalah dokumen peraturan perundangundangan dan bahasa pustaka. Metode pendekatan ini sangat efektif dengan menganalisis ketentuan-ketentuan yang berkait erat dengan masalah penegakan hukum dalam proses sistem peradilan pidana, karena pendekatan yuridis normatif untuk mengetahui sejauh mana asasasas hukum, sinkronisasi vertikal/horizontal, dan sistemik hukum diterapkan. 
Bertolak dari pendekatan penelitian di atas, maka spesifikasi penelitian yang digunakan bersifat deskriptif analitis. Oleh karena penelitian ini termasuk dalam penelitian hukum normatif. Maka sumber dan jenis data yang digunakan ialah data sekunder. Data sekunder yang diteliti antara lain:

1. Bahan Hukum Primer

Bahan hukum primer yaitu bahan hukum yang mengikat, seperti sumber-sumber hukum nasional yang berkaitan, sebagai berikut:

1) Undang-undang Nomor 8 Tahun 1981 Tentang Hukum Acara Pidana (KUHAP)

2) Surat Edaran MA Nomor 1 Tahun 2020 tentang Pedoman Pelaksanaan Tugas Selama Masa Pencegahan Penyebaran Covid-19

2. Bahan Hukum Sekunder

Bahan hukum sekunder yakni buku teks yang berisi prinsip-prinsip dasar ilmu hukum dan pandangan-pandangan klasik para sarjana yang mempunyai kualifikasi tinggi.

\section{Bahan Hukum Tersier}

Bahan hukum tersier yakni petunjuk atau penjelasan mengenai bahan hukum primer atau bahan hukum sekunder seperti kamus hukum, ensiklopedia, indeks kumulatif.

Selanjutnya pengumpulan data dilakukan dengan menggunakan penelitian kepustakaan dan studi dokumen yaitu dengan menginventarisir dan memahami berbagai isi bahan hukum primer dan bahan hukum sekunder. Tenik ini berguna untuk mendapatkan landasan teori dengan mengkaji dan memperlajari buku-buku, peraturan perundangundangan, dokumen, laporan, arsip, dan penelitian lainnya baik cetak maupun elektronik.

Data yang telah diperoleh, selanjutnya akan dianalisis secara kualitatif. Metode analisis data secara kualitatif yakni melakukan upaya dengan jalan bekerja melalui data, mengorganisasikan data, memilah-milahnya menjadi satuan yang dapat dikelola, mensintesiskannya, mencari dan menemukan pola, sesuatu yang dapat menemukan hal yang penting dan hal yang dipelajari, dan memutuskan sesuatu yang dapat diceritakan kepada orang lain atau yang mendeskripsikannya, serta dengan menafsirkan dan mengkonstruksikan pernyataan yang terdapat dalam dokumen dan perundang-undangan.

\section{HASIL DAN PEMBAHASAN}

Dalam upaya pencegahan Covid-19 di bidang penegakan hukum, Pandemi COVID-19 yang telah melanda Indonesia sejak Maret lalu tidak saja berdampak pada sektor kesehatan, perekonomian, politik melainkan juga berpengaruh pada bidang penegakan hukum, khususnya dalam proses persidangan di lembaga peradilan. Proses persidangan yang bertahun-tahun digelar konvensional. Penasihat hukum, jaksa, hakim dan terdakwa bertemu dalam sebuah persidangan yang terbuka untuk umum. Sejak pandemi melanda, persidangan tatap muka harus diganti virtual dengan memanfaatkan kecanggihan teknologi. Hakim, jaksa dan penasihat hukum tidak harus bertemu dengan terdakwa di dalam persidangan. Mata hanya menatap layar monitor besar yang ditaruh di depan persidangan. Hakim dan jaksa berkomunikasi dengan terdakwa dengan bantuan teknologi dan komunikasi. Penasihat hukum 
pun demikian, ia berada di lembaga pemasyarakatan (lapas) mendampingi kliennya [10]. Status darurat Covid-19 telah berdampak pada krisis di semua aspek kehidupan, tidak terkecuali dalam aspek dunia hukum. Hukum pidana formil yang menjadi dasar hukum acara dalam penanganan perkara pidana tengah dalam keadaan darurat yang ketentuannya banyak disimpangi karena disesuaikan dengan keadaan. Jargon legalitas yang selalu diagungkan menjadi tidak berdaya dalam menghadapi keadaan darurat, dan hierarki peraturan perundangundangan tidak dapat lagi berfungsi secara maksimal dalam situasi yang tidak normal.

Penegakan hukum dalam ranah hukum pidana berjalan dalam sebuah sistem yang disebut dengan sistem peradilan pidana (criminal justice system). Istilah tersebut untuk menunjukkan mekanisme kerja dalam penanggulangan kejahatan dengan mempergunakan dasar pendekatan sistem. Sistem peradilan pidana yang disebut juga dengan criminal justice process dimulai dari proses penyelidikan/penyidikan, penuntutan, dan pemeriksaan di muka pengadilan, serta diakhiri dengan pelaksanaan pidana di lembaga pemasyarakatan. Rangkaian komponen sistem peradilan pidana terpadu (integrarted criminal justice system) yang terdiri dari lembaga Kepolisian, Kejaksaan, Pengadilan, dan Pemasyarakatan sedang dihadapkan pada kondisi extra ordinary yang memerlukan alur penanganan secara tidak biasa. Imbauan mengurangi kontak fisik dengan cara bekerja dari rumah (work from home/WFH) dengan tagar "dirumahsaja" tidak dapat sepenuhnya dilakukan oleh para pelaku teknis sistem peradilan pidana.

Salah satu solusi yaitu tahapan penanganan perkara pidana dengan sistem tatap muka secara konvensional telah dimodifikasi menjadi tatap muka secara digital melalui sistem ecourt. Para pihak yang awalnya berada dalam satu tempat sakral dalam ruang sidang Kantor Pengadilan menjadi terpisah-pisah berada di dalam kantor masing-masing, dengan gambaran umum yaitu para Hakim berada di ruang sidang Kantor Pengadilan, Penuntut Umum, saksisaksi, dan/atau ahli berada di Kantor Kejaksaan, serta terdakwa dan penasihat hukumnya berada di Kantor Rumah Tahanan Negara (Rutan). Para pihak kemudian dipertemukan dalam sistem jaringan berbasis aplikasi meeting dalam sebuah teleconference memanfaatkan teknologi internet saat ini. Perangkat seperti web camera, speaker/michrophone, monitor, dan PC/laptop menjadi sarana wajib dalam sebuah sidang online. Tentunya hal ini menjadi sebuah solusi inovasi yang harus diapresiasi di tengah kondisi darurat covid-19 saat ini.

Di dalam proses penegakan hukum, ada tiga hal tujuan yang harus diperhatikan, yaitu kepastian hukum, kemanfaatan dan keadilan. Kepentingan penegakan hukum untuk kepastian hukum berdasarkan peraturan perundang-undangan, dan kepentingan penegakan hukum untuk kepentingan keadilan dalam masyarakat seringkali terjadi benturan. Tidak terkecuali dalam kondisi saat ini di masa pandemi Covid-19, hukum acara yang menjadi landasan penegakan hukum sudah tidak lagi dapat sepenuhnya digunakan sehingga terjadi transisi grey area antara kepastian dan keadilan. Tanggap situasi darurat covid-19 ini telah menjadikan alur penegakan hukum relatif berjalan secara kacau, sehingga masing-masing instansi mengeluarkan peraturan internal tentang penanganan perkara pidana dalam situasi darurat Covid-19.

Kementerian Hukum dan Ham sebagai induk dari Rumah Tahanan Negara (Rutan) telah mengeluarkan aturan penghentian sementara penerimaan tahanan baru yang tentunya memberikan domino effect dalam penegakan hukum yang sedang atau akan berjalan baik di Kepolisian atau pun di Kejaksaan. Dilanjutkan dengan aturan internal yang dikeluarkan oleh Kejaksaan atau pun Kepolisian yang mengedepankan koordinasi penundaan tahapan proses penanganan atau pun pengalihan jenis tahanan serta Mahkamah Agung juga telah 
mengeluarkan aturan tentang penerapan sidang melalui teleconference. Aturan internal yang kemudian dijadikan dasar pijakan ini bertujuan untuk memberikan perlindungan hak asasi dan menjamin ketepatan durasi penanganan penegakan hukum di tengah kondisi krisis keadaan.

Suatu pembaharuan dari pembentukan dasar hukum terhadap penegakan hukum dalam proses sistem peradilan pidana dengan tujuan lebih responsif. Urgensi dilakukan pembaharuan hukum acara pidana nasional di Indonesia dengan pembentukan dasar hukum yang lebih responsif, karena hukum acara pidana (KUHAP) pada masa pandemi Covid-19 dipandang tidak sesuai lagi. KUHAP sebagai pedoman dasar dalam proses pelaksanaan perkara pidana hanya mengatur hal-hal yang sifatnya normal [11]. Di dalam penegakan hukum sebagai landasan tegaknya supremasi hukum, tidak saja menghendaki komitmen ketaatan seluruh komponen bangsa terhadap hukum, tetapi mewajibkan aparatur penegak hukum menegakan dan menjamin kepastian hukum. Di dalam menegakan dan menjamin kepastian hukum, tindakan aparatur penegak hukum secara formal harus ada pengaturannya, agar tindakannya tidak kontradiktif dengan undang-undang. Artinya tidak saja mengacu kepada ketentuan hukum pidana materil tetapi juga mengacu kepada hukum pidana formil yang lazim disebut dengan hukum acara pidana.

Hukum acara pidana tertuju kepada dua sasaran pokok yaitu usaha melancarkan jalannya proses penerapan hukum pidana oleh alat perlengkapan negara yang berwenang dan jaminan hukum bagi setiap orang untuk menghindari tuntutan atau hukuman yang bertentangan dengan hak asasi manusia. Dengan demikian, keberadaan (eksistensi) dari hukum acara pidana sangat dibutuhkan dalam rangka memberikan ketertiban, ketentraman, kepastian dan keadilan.

Meskipun pemerintah Indonesia sudah mengeluarkan sejumlah kebijakan guna mendukung penegaka hukum dalam proses sistem peradilan pidana di masa pandemi Covid19, proses penegakan hukum dalam penanganan perkara tindak pidana yang menjadi tugas para penegak hukum di masa pandemi Covid-19 dibutuhkan seperangkat peraturan yang dapat mengakomodir proses penyelesaian perkara pidana sesuai dengan asas yang berlaku mengikuti protokol kesehatan Covid-19 untuk menyelesaikan perkaranya secara baik dan adil. Dengan demikian melihat keadaan saat ini di masa pandemi Covid-19 dalam rangka penegakan hukum yang berorientasi kepastian hukum dan berdimensi keadilan diperlukan revisi KUHAP atau adanya aturan hukum PERMA dengan memperhatikan aspek prosedural, subtansial dan petunjuk pelaksanaan persidangan virtual bagi seluruh pihak agar dapat memberikan perlindungan dan pengakuan terhadap hak-hak asasi dan membatasi tindakan sewenang-wenang aparat penegak hukum dalam penyelesaian dan penanganan perkara. 
Seminar Nasional Penelitian dan Pengabdian kepada Masyarakat Universitas Sang Bumi Ruwa Jurai Tahun 2020

\section{KESIMPULAN}

Penegakan hukum dalam ranah hukum pidana berjalan dalam sebuah sistem yang disebut dengan sistem peradilan pidana (criminal justice system) dimulai dari proses penyelidikan/penyidikan, penuntutan, dan pemeriksaan di muka pengadilan, serta diakhiri dengan pelaksanaan pidana di lembaga pemasyarakatan. Selama masa pandemi Covid-19 proses sistem peradilan pidana di Covid-19 digelar secara virtual. Urgensi pembentukan dasar hukum terhadap proses peradilan pidana yang lebih responsif, karena hukum acara pidana (KUHAP) pada masa pandemi Covid-19 dipandang tidak sesuai lagi. KUHAP sebagai pedoman dasar dalam proses pelaksanaan perkara pidana hanya mengatur hal-hal yang sifatnya normal.

\section{DAFTAR PUSTAKA}

Handri Kristanto \& Nyoman Serikat Putra Jaya. (2020). Hospital Criminal Liability as a Corporation of Patient Rejection I Infected with Covid-19. Legality: Jurnal Ilmiah Hukum, 28(2), 146-157.

Dewi Rahmaningsih Nugroho \& Suteki. (2020). Membangun Budaya Hukum Persidangan Virtual (Studi Perkembangan Sidang Tindak Pidana via Telekonferensi. Jurnal Pembangunan Hukum Indonesia, 2(3), 291-304.

Achmad Budi Waskito. (2018). Implementasi Sistem Peradilan Pidana Dalam Perspektif Integrasi. Jurnal Daulat Hukum, 1(1), 287-304.

Nyoman Satyayudhadananjaya. (2014). Sistem Peradilan Pidana Terpadu. Jurnal Ilmiah Ilmu Agama dan Ilm Hukum, 9(1), 88.

Michael Barama. (2016). Model Sistem Peradilan Pidana Dalam Perkembangan, Jurnal Ilmu Hukum, 3(8), 8-17.

Pujiyono. (2012). Rekonstruksi Sistem Peradilan Pidana Indonesia. Jurnal MIH, 41(1), 120

Achmad Budi Waskito. (2018). Implementasi Sistem Peradilan Pidana Dalam Perspektif Integrasi. Jurnal Daulat Hukum, 1(1), 293.

Armunanto Hutahaean \& Erlyn Indarti. (2019). Lembaga Penyidik Dalam Sistem Peradilan Terpadu Di Indonesia. Jurnal Legislasi Indonesia, 16(1), 35.

Soerjono Soekanto. (2010). Faktor-Faktor Yang Mempengaruhi Penegakan Hukum. Jakarta: PT Raja Grafindo.

Zennis Helen. Disrupsi Pengadilan di Tengah Pandemi Covid-19. Diakses melalui https://kawanhukum.id/disrupsi-pengadilan-di-tengah-pandemi-covid-19.

M.Zen Abdullah. (2020). Urgensi Perlunya Pembaharuan Hukum Acara Pidana Nasional Di Indonesia yang Lebih Responsif. Jurnal Ilmiah Universitas Batanghari Jambi, 20(1), 281-287. 
Seminar Nasional Penelitian dan Pengabdian kepada Masyarakat Universitas Sang Bumi Ruwa Jurai Tahun 2020 